\title{
Macroeconomic Drivers of Private Equity Penetration in Sub-Saharan African Countries
}

\author{
Fonkam Mongwa Nkam ${ }^{1}$, Akume Daniel Akume ${ }^{2}$, Molem Christopher Sama ${ }^{3}$ \\ ${ }^{1} \mathrm{PhD}$ Student, Department of Banking and Finance, Faculty of Social and Management Sciences, University of \\ Buea, Cameroon \\ ${ }^{2}$ Higher Technical Teacher Training College (HTTTC), University of Buea, Kumba, Cameroon \\ ${ }^{3}$ Department of Economics, University of Buea, Cameroon \\ Correspondence: Fonkam Mongwa Nkam, Department of Banking and Finance, Faculty of Social and \\ Management Sciences, University of Buea, Cameroon.
}

Received: November 21, 2019

Accepted: December 16, 2019 Online Published: December 19, 2019

doi:10.5539/ibr.v13n1p192

URL: https://doi.org/10.5539/ibr.v13n1p192

\begin{abstract}
The objective of this study is to investigate in to the drivers of private equity penetration in Cameroon, Nigeria, Ghana, Kenya and South Africa. Secondary data was collected from private equity and venture capital data bases (CapitalIQ, Preqin, Burgiss and Mergermarket), World Bank development indicators, regional private equity and venture capital associations and country specific stock market websites. The Panel Two-Stage Least Squares Instrumental Variables (2SLS IV), Panel Corrected Standard Errors (PCSE) and Feasible Generalised Least Squares (FGLS) estimation techniques were used. This was due to potential problems of endogeneity and spherical errors of serial correlation, heteroskedasticity, cross sectional dependence and multicollinearity. The results using the 2SLS IV estimation technique show that stock market capitalisation, GDP per capita, banking credit to private sector, real exchange rate and private investments are key macroeconomic drivers of private equity penetration in the selected Sub-Saharan African countries. Inflation had negative and insignificant effect on private equity penetration in the selected countries. The results using the PCSE and FGLS estimation techniques show that the signs of all the variables remain the same as was the case in the 2SLS IV estimation technique though the magnitudes were different. However, the results of PCSE and FGLS estimation techniques show that banking credit to private sector is significant in the FGLS model while private investments is significant in the PCSE model. GDP per capita, real exchange rate, stock market capitalisation and inflation are significant in both the PCSE and FGLS estimation techniques.
\end{abstract}

Keywords: macroeconomic drivers, private equity penetration, SSA

\section{Introduction}

Development and finance literature suggests that financial development is beneficial for attracting capital. Development literature further confirms the private sector as the main driver of economic growth (European Venture Capital Association [EVCA], 2013). The private sector needs to be adequately capitalised for any country to be developed. By Private equity (PE) we include Venture Capital (VC). This is because private equity firms today invest in all the stages of companies that are not quoted on capital markets. PE investors are known to provide seed, venture, growth and distress capital to companies from small to medium sized. This has made the PE industry to explode in scale and scope and has become a significant component of the global financial market (Ernst \& Young [EY], 2018). Companies that are backed by PE investors are more efficient and create more employment than their peers (Belke, Fehn, \& Foster-McGregor, 2003). In order to increase their returns, PE firms are seeking to penetrate developing markets. This is due to strong competition, saturation and depletion of deals in developed markets. By private penetration, we mean Private equity and venture capital deal flows to a particular country based on some attractive or unattractive factors.

Developing countries are still in the transformation process and access to capital is a problem. As a consequent, businesses have difficulties in sourcing finance for growth and expansion. This problem is more serious for young companies with weak and unattractive balance sheets for commercial bank loans. This has caused some businesses not to exploit their potentials. In extreme cases some have simply discontinued operations (Cressy, 
Munari, \& Malipiero 2007). In the wake of these difficulties, PE financing is an alternative source of funding for businesses. This is because it provides finances to all stages in a business' lifecycle. By so doing, they can bridge the gap between a company self-financing and obtaining funds from banks. Faced with the challenges of business financing and achieving ambitious economic emergence objectives, many governments in Sub Sahara countries are thriving to make their economies attractive to private equity investors. However, some PE investors still perceive Sub Sahara as a region of high risk, over-indebtedness, high volatile exchange rates, low middle class, poor infrastructure and poor financial sector (Leamon \& Lerner, 2011).

Despite these perceptions, governments in the sub-Saharan region are creating enabling environments with an attractive PE penetration profile (International Monetary Fund [IMF], 2015). However, some of these countries have been attractive while others have simply been unattractive to PE investors. For the purpose of this paper, five countries (Nigeria, Ghana, Kenya, Cameroon and South Africa) have been selected. From 2013 to 2018, these countries were the most attractive to private equity investors in their respective sub-regions. In West Africa, out of 282 completed deals, Nigeria had 54\% and Ghana 22\%. In terms of deal value to West Africa, Nigeria had $73 \%$ and Ghana $20 \%$ of U.S $\$ 10.8$ billion. In East Africa, of the 194 reported number of PE deals Kenya alone had 58\%. Within this same period, U.S \$2.4 billion deal value was reported in East Africa and Kenya had 59\%. In Southern Africa, there were 295 number of PE deals and South Africa alone had $66 \%$. There was U.S \$ 3.5 billion value of reported deals to Southern Africa and South African grabbed 70\% share (Africa Private Equity and Venture Capital Association [AVCA], 2019). In Cameroon, PE activity is timid and only one Merger and Acquisition deal had been completed through the Douala Stock Exchange (AVCA, 2019).

Most research on the determinants of private equity activity has been on developed countries. Among them are the studies of Groh and Liechtenstein (2010), Kelly (2012), Aizenman and Kendall (2008), Clarysse, Knockaert, \& Wright (2009), Guler and Guillén (2010), Cherif and Gazdar (2011), Félix, Pires and Gulamhussen (2013), Oino (2014) and Bernoth and Colavecchio (2014). However, Oni (2017) conducted a study on the determinants of venture capital supply in Sub-Saharan Africa. Due to low PE penetration, policy makers in the selected countries have made considerable efforts to liberalise their financial sectors and attract more private equity. Cameroon passed the 2013 Act in order to improve its investment climate (Ministry of economy, Planning and Regional Development, 2013). Nigeria formulated reforms to reduce the risk factors to investors (Securities Exchange Commission [SEC], 2016). Ghana passed the Venture Capital Trust Fund Act in 2004 and financing schemes legislations (Owusu-Adjei, 2010). Kenya enacted the investment act in 1989, revamped corporate laws, granted incentives of lower capital gains tax rate to PE firms on exit and enacted the Walker guidelines in England on transparency (Njubi, 2018). South Africa relaxed regulations on Johannesburg Stock exchange (JSE) listing requirements and profits repatriation laws (Molatlhwe, 2016).

Despite the national financial liberalisation reforms, private equity penetration in the selected countries continues to be low. This poses a problem as current literature and policies have failed to provide concrete suggestions and solutions. This presents significant policy and knowledge gaps. Therefore, this research is motivated by the failure of current academic literature and policies to investigate in to the macroeconomic drivers of private equity penetration in Cameroon, Nigeria, Ghana, Kenya and South Africa. Thus, this study seeks to fill the knowledge and policy gaps by providing results that will increase PE investments in these countries. Based on this, the objective of this study is to investigate in to the macroeconomic drivers of private equity penetration in Cameroon, Nigeria, Ghana, Kenya and South Africa.

\section{Theoretical and Literature Review}

Private equity penetration can be explained using the Modigliani and Miller (1958) trade-off theory and the Pecking Order theory of Myers (1984). The trade-off theory posits that businesses are financed using either debt or equity capital. However, debt financing is unattractive as it puts financial pressure on businesses in terms of interest payments and principal repayments. Due to these constrains, businesses prefer equity financing. This makes private equity funding a major and attractive source of business finance. According to the pecking order theory, there are three sources of funding to businesses. These are internal, debt and equity financing. When private equity activity in increased in a country, businesses benefit from equity financing. This boosts growth and expansion with less financial pressure in the form of interest payments and principal repayments.

The attractiveness of private equity financing to a country or region can be explained by the neoclassical theory of investment behaviour developed by Jorgenson (1971) and the Modern Portfolio Theory (MPT) of Markowitz (1952). The neoclassical theory of investment behaviour theory posits that firms invest if their current capital stock is smaller than the optimal capital stock and disinvest when their current capital stock is sufficiently larger than the optimal capital stock. In studies of PE investments, this theory refers to the idea that PE investments 
tend to cluster in regions/countries of economic, technological or regulatory advancements (Yan, 2011). The demand side comprises businesses seeking financing. This means that the demand for private equity as a source of financing should be higher in times of positive economic prospects. The supply side consists of private investors looking for investment opportunities with attractive risk-return characteristics. These are based on some attractive and unattractive macroeconomic and institutional forces such as GDP per capita, inflation, real exchange rates, banking sector development, capital markets, rate of savings and corruption.

From the assumptions of the MPT, risk-averse investors can construct portfolios to optimise or maximise expected return based on a given level of portfolio risk. They seek to control risk only through diversification. In their international allocation strategies to minimise risks, private equity investors make their international allocation decisions by investing in countries that have low macroeconomic and institutional risk profiles with the aim of increasing their returns.

In addition to the theories are some empirical duties that explain the macroeconomic derivers of private equity penetration. Groh and Liechtenstein (2010) undertook a study to determine the attractiveness of Central and Eastern Europe for risk capital investors. Based on questionnaires addressed to institutional investors, they found stock market capitalisation to attract private equity funding. Clarysse et al. (2009) used a panel technique to identify supply and demand drivers of venture capital activity for the UK (1985-2006), Israel (1999-2007) and the US (1980-2007). They found that the amounts of early stage and total VC invested in these countries are determined by total entrepreneurial activity (as measured by the Global Entrepreneurship Monitor) and stock market capitalisation.

Aizenman and Kendall (2008) investigated the internationalisation of venture capital and private equity investments using gravity analysis covering three decades and 100 countries. The results showed that better business environment and deeper financial markets were important local factors that attract international venture capital. Kelly (2012) investigated the drivers of private equity activity by undertaking a panel data study for 17 European countries. By using the Generalised Method of Moments estimator they found market capitalisation to be an important determinant of PE activity.

Cherif and Gazdar (2011) examined the determinants of venture capital investments across 21 European countries from 1997-2006. By using the Generalised Least Squares estimator, they found that GDP growth and market capitalisation were the most macroeconomic determinants of European venture capital investments. Guler and Guillén (2010) conducted a study on the institutions and the internationalisation of 216 U.S venture capital firms investing in 95 countries during the 1990 -2002 period. The results showed that venture capital and private equity firms invest in host countries characterised by good financial institutions and exits through capital markets. Félix et al. (2013) conducted a study on the determinants of venture capital in Europe. By using an aggregate data from 23 European countries for the period 1998-2003 to estimate panel data models with fixed and random effects, they found that stock market capitalisation had a positive impact on venture capital activity.

Oino (2014) studied the macroeconomic and environment determinants of private equity in emerging Asian markets. By using the extreme bound analysis, the results showed that while GDP growth and market capitalisation did not result to be significant. Private equity was more accessible in countries with well-developed stock markets. Bernoth and Colavecchio (2014) studied the macroeconomic determinants of private equity investment by comparing 16 Central and Eastern European (CEE) and Western European countries from 2001 to 2011. By applying the extreme bound analysis, their results suggested that GDP per capita, commercial bank lending, inflation rate and equity market capitalisation were significant determinants of PE activity. Oni (2017) carried out a study on the determinants of venture capital supply in Sub-Saharan Africa from 2006 to 2015. The objective was to determine the variables that influence venture capital supply in 8 Sub-Saharan African countries (Botswana, Ivory Coast, Ghana, Kenya, Mauritius, Nigeria, South Africa and Uganda). By using Panel data models of pooled, fixed and random effects, the results showed that there is a significant positive relationship between initial public offering, market capitalisation and venture capital supply.

\section{Methodology}

\subsection{Sources of Data}

Secondary data was collected from 2002 to 2017. It was collected from CapitalIQ, Preqin, Mergermarket, World Bank indicators, monthly and annual data from private equity and venture capital association reports such as the African Venture Capital Association (AVCA), East Africa Venture Capital Association (EAVCA) and South Africa Venture Capital Association (SAVCA). 


\subsection{Model Specification}

We used three estimators, namely Two-Stage Least Squares, Instrumental Variables (2SLS, IV), Panel Corrected Standard Errors (PCSE) and Feasible Generalised Least Squares (FGLS). The analyses began with the Panel Instrumental Variable (IV) based on the fact that endogeneity may exist. Thus, a simple Fixed or Random Effect estimation would have produced biased results if this is true. The estimation was conducted using the XTIVREG2 command in STATA 13. The XTIVREG2 implements IV/GMM estimation of the fixed-effects and first-differences panel data models with possible endogenous regressors. This command is robust in this situation because of heteroskedasticity and serial correlation within the panels. The traditional panel data estimators-Fixed Effects (FE) model, Random Effects (RE) model and Ordinary Least Squares (OLS) are used by assuming consistency but in this situation they are ineffective to deal with. The 2SLS, IV estimation technique was used because of potential endogenous regressors. The PCSE proposed by Beck and Katz (1995) and FGLS estimator of Parks (1967) were used because of the existence of spherical errors (cross sectional dependency, heteroskedasticity and serial correlation) after testing. Both the PCSE and FGSL models were used because the PCSE estimator provides accurate standard error estimations with little loss in efficiency than the FGLS. However, the FGLS has an efficiency advantage over the PCSE when the number of time periods (T) is at least twice the number of cross-sectional units (Park, 1967). In this study, T (16) is trice the $\mathrm{N}(5)$ thus calling for the use of FGLS.

The empirically derived variables used in the models were stock market capitalisation, GDP per capita, banking credit to private sector, private investments, inflation and real exchange rates. The choice of variables was backed by the empirical Kelly (2012), Aizenman and Kendall (2008), Clarysse et al. (2009), Oino (2014) Bernoth and Colavecchio (2014). We used market capitalisation (proxy of capital market development) because private equity investors use capital markets for deal valuations and during divestments. Therefore the development level of a country's capital market is essential to private equity investors. We equally used GDP per capital because per capita income determines the amounts of goods and services produced by private equity backed companies that are bought by the population. Banking credit to private sector was used because the amount of credit granted by domestic financial institutions will determine the need for additional financing that could be provided by private equity investors. Inflation was used to model for macroeconomic stability. This is because it affects the prices of goods produced by private equity backed firms and ultimately the returns of private equity investors. This study equally included private investments and real exchange rates as drivers of private equity penetration. This is because empirically, private investment is used as a driver of financial sector development and real exchange rate as a determinant of private investments. The rationale is that private equity is a financial service that provides loans for private investments. If real exchange rates can affect private investments they could equally affect private equity investments. Finally, exchange rate uncertainty affects the value of cross-border investments. Institutional variables will be considered in our next study. The linear form of the PE penetration model is given as;

$$
P E P=f(M C A P, G D P P C, B C P, P I, I N F, R E R)
$$

The fixed effect, 2SLS, IV model is specified as;

$$
\ln P E P_{i t}=\beta_{0}+\beta_{1} \ln M C A P_{i t}+\beta_{2} \ln G D P P C_{i t}+\beta_{3} \ln B C P_{i t}+\beta_{4} \ln P I_{i t}+\beta_{5} \ln I N F_{i t}+\beta_{6} \ln R E R_{i t}+\mathcal{u}_{i t}+\varepsilon_{i t}
$$

The regression model for the Panel Corrected Standard Errors (PCSE) and Feasible Generalised Least Squares (FGLS) model is specified as;

$$
\ln P E P_{i t}=\beta_{0}+\beta_{1} \ln M C A P_{i t}+{ }_{?} \beta \ln G D P P C_{i t}+\operatorname{ll}_{⿺ ⿻ 十}+\beta_{3} \ln B C P_{i t}+\beta_{4} \ln P I_{i t}++\beta \operatorname{lnINF} F_{i t}+\beta_{6} \ln R E R_{i t}+U_{i t}
$$

Where

$\beta_{0}$ is a constant, $\beta_{1}, \beta_{2}, \beta_{3}, \beta_{4}, \beta_{5}$ and $\beta_{6}$ are coefficients of the independent variables in the PEP model. it is the individual country in year $t, \ln$ is Natural Logarithm, $\varepsilon$ is the errors autocorrelated along t. From empirical studies, the a priori was for the coefficients of the independent variables $\beta_{1}, \beta_{2}, \beta_{3}$ and $\beta_{4}$ to be positive while those of $\beta_{5}$ and $\beta_{6}$ to be negative.

PEP is Private Equity Penetration. It is the level of private equity deals flow to a country as a proportion of its 
lagged GDP. Given the lag between economic development and possibility of investment, we take GDP of previous year. PE penetration can be measured using GDP as a proxy.

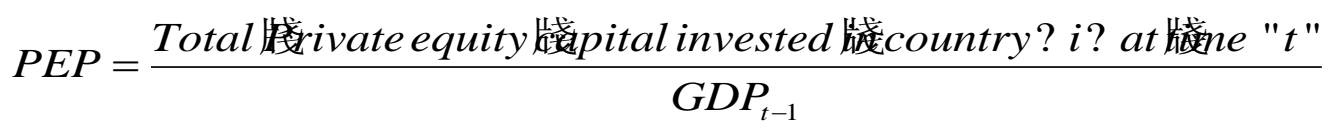

MCAP is stock market capitalisation and it is the market value of outstanding shares of listed home companies. It is measured as a percentage of market value of outstanding shares to GDP. It is used as proxy of capital market development.

BCP is banking credit to private Sector and it is the total credit granted to the private sector for production purposes by financial institutions in a country. It measured as the percentage of total Credit to private Sector by financial institutions to GDP.

GDPPC is GDP per capita and it is a ratio of a country's gross domestic product to its total population. It is measured by dividing a country's GDP to its total population.

PI is Private Investments and it is gross outlays by the private sector (including private non-profit agencies) on additions to its fixed domestic assets. It is measured as gross national investments divided by GDP.

INF is inflation rate and it is an indication of the general price level in a country and macroeconomic instability. It is measured using the Consumer Price Index (CPI).

RER is real exchange rate. It is an indicator of exchange rate risk and certainty in the economy. It is measured using the value of the currencies of the selected countries against a weighted average of several other currencies divided by a price deflator or index of costs.

\section{Descriptive Statistics}

In order to better understand the distribution of the variables, the descriptive are presented per country.

Table 1. Private Equity Penetration (\% of GDP)

\begin{tabular}{lccccc}
\hline Year & Cameroon & Ghana & Kenya & Nigeria & South Africa \\
\hline 2002 & 0.003155 & 0.010327 & 0.014656 & 0.083913 & 0.099432867 \\
2003 & 0.006887 & 0.027788 & 0.015918 & 0.113026 & 0.102280363 \\
2004 & 0.007199 & 0.028684 & 0.021596 & 0.116287 & 0.23889248 \\
2005 & 0.007407 & 0.035241 & 0.039007 & 0.109233 & 0.236688135 \\
2006 & 0.007679 & 0.036073 & 0.049652 & 0.10128 & 0.317720768 \\
2007 & 0.008636 & 0.027839 & 0.046259 & 0.128037 & 0.367648787 \\
2008 & 0.00932 & 0.075779 & 0.047375 & 0.139143 & 0.340221391 \\
2009 & 0.012286 & 0.088069 & 0.058393 & 0.163988 & 0.365685456 \\
2010 & 0.133988 & 0.108259 & 0.078065 & 0.256164 & 0.367225789 \\
2011 & 0.014317 & 0.096698 & 0.095 & 0.281742 & 0.353983633 \\
2012 & 0.013288 & 0.120992 & 0.102018 & 0.298258 & 0.357494745 \\
2013 & 0.014031 & 0.138584 & 0.117036 & 0.315389 & 0.385709836 \\
2014 & 0.020454 & 0.159807 & 0.103454 & 0.317373 & 0.362389242 \\
2015 & 0.019734 & 0.18679 & 0.113101 & 0.365003 & 0.388059066 \\
2016 & 0.022774 & 0.18324 & 0.128764 & 0.386221 & 0.428509535 \\
2017 & 0.021984 & 0.184389 & 0.130397 & 0.381001 & 0.439793931 \\
\hline
\end{tabular}

Source. Compiled by Author, 2019

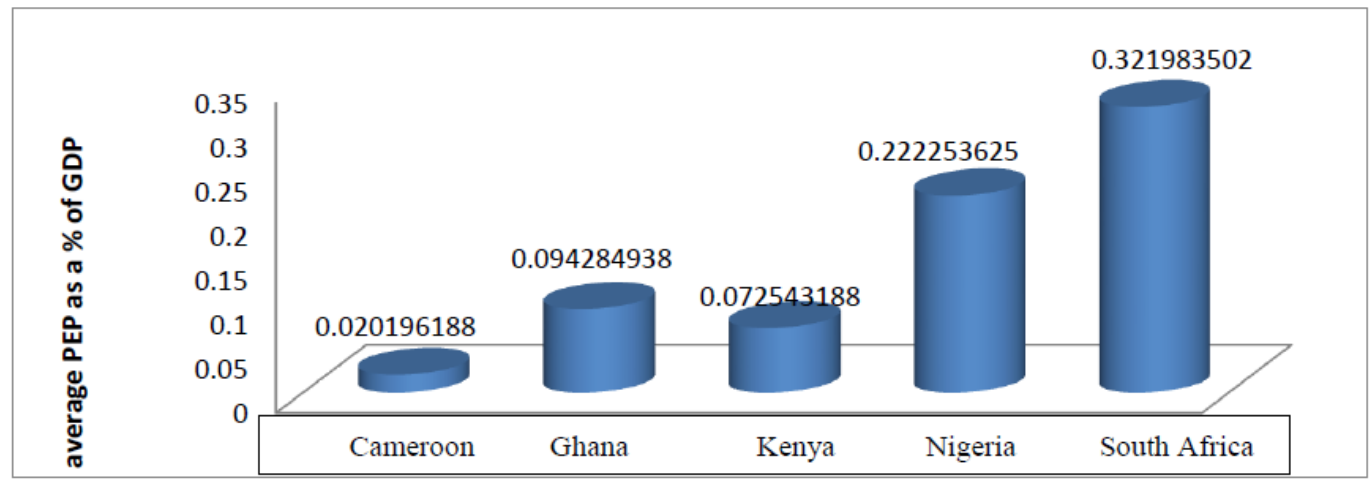

Figure 1 . Average private equity deal flow per country 
Tables 2, 3, 4, 5 and 6 below show mean, standard deviation, minimum and maximum values of all the variables used per country. The number of observations (N) is 16 years (2002 to 2017).

Table 2. Cameroon

\begin{tabular}{llcccc}
\hline & $\mathbf{N}$ & Mean & Std. Dev. & Min & Max \\
\hline pep & 16 & 65260.96 & 14207.32 & 41190.55 & 107158.9 \\
Inf & 16 & 2.198227 & 1.499817 & 0.233647 & 5.337806 \\
Rer & 16 & 100.405 & 2.433143 & 96.54008 & 106.6273 \\
gdppc & 16 & 1254.587 & 239.5355 & 719.8896 & 1571.182 \\
bcp & 16 & $3.06 \mathrm{E}+09$ & $1.46 \mathrm{E}+09$ & $9.97 \mathrm{E}+08$ & $5.06 \mathrm{E}+09$ \\
Pi & 16 & $5.81 \mathrm{E}+09$ & $1.80 \mathrm{E}+09$ & $2.64 \mathrm{E}+09$ & $8.41 \mathrm{E}+09$ \\
mcap & 16 & $4.03 \mathrm{E}+10$ & $4.64 \mathrm{E}+10$ & $1.68 \mathrm{E}+09$ & $1.28 \mathrm{E}+11$ \\
\hline
\end{tabular}

From table 1 above, the mean of PEP is 65260.96. The minimum and maximum values are 41190.55 and 107158.9 respectively. There is low variability from the mean as shown by the low standard deviation value of 14207.32. The mean of the inflation variable (inf) is 2.198227. The minimum and maximum values are 0.233647 and 5.337806 respectively. It has a low standard deviation (1.4998170), thus low variability in the distribution of this variable from the mean. The mean of the real exchange rate (rer) is 100.405 . The minimum and maximum values are 96.54008 and 106.6273 respectively. It has a low standard deviation value of 2.433143 . The average of the GDP per capita (gdppc) is 1254.587. The minimum and maximum values are 719.8896 and 1571.182 respectively. The standard deviation $(239.5355)$ is low. This means that there is a low variability in the distribution of this variable from the mean. The mean of the banking credit to private sector (bcp) is 3.06E+09. The minimum and maximum values are $9.97 \mathrm{E}+08$ and $5.06 \mathrm{E}+09$ respectively. There is high variability from the mean as portrayed by its high standard deviation value of $1.46 \mathrm{E}+09$. The average value of the private investments (pi) variable is $5.81 \mathrm{E}+09$. The minimum and maximum values are $2.64 \mathrm{E}+09$ and $8.41 \mathrm{E}+09$ respectively. There is low variability in the distribution of this variable from the mean as shown by the low standard deviation value of $1.80 \mathrm{E}+09$. Market capitalisation (mcap) variable has a mean value of $4.03 \mathrm{E}+10$. The minimum and maximum values are $1.68 \mathrm{E}+09$ and $1.28 \mathrm{E}+11$ respectively. The standard deviation value of $4.64 \mathrm{E}+10$ is high. This means that there is high variability of this variable from the mean.

Table 3. Ghana

\begin{tabular}{|c|c|c|c|c|c|}
\hline & $\mathbf{N}$ & Mean & Std. Dev. & Min & Max \\
\hline pep & 16 & 137638.7 & 54465.39 & 85358.81 & 230548 \\
\hline Inf & 16 & 14.20924 & 4.73252 & 7.12635 & 26.67495 \\
\hline Rer & 16 & 91.1858 & 12.16606 & 68.3678 & 107.5895 \\
\hline gdppc & 16 & 1288.467 & 661.8778 & 309.4845 & 2401.754 \\
\hline bcp & 16 & $4.80 \mathrm{E}+09$ & $2.84 \mathrm{E}+09$ & $7.49 \mathrm{E}+08$ & $8.45 \mathrm{E}+09$ \\
\hline $\mathbf{P i}$ & 16 & $7.36 \mathrm{E}+09$ & $5.58 \mathrm{E}+09$ & $1.21 \mathrm{E}+09$ & $1.67 \mathrm{E}+10$ \\
\hline mcap & 16 & $2.74 \mathrm{E}+09$ & $1.75 \mathrm{E}+09$ & $3.50 \mathrm{E}+08$ & $5.71 \mathrm{E}+09$ \\
\hline
\end{tabular}

Table 3 above shows that private equity penetration (pep) in Ghana has a mean of 137638.7. The minimum and maximum values are 85358.81 and 230548 respectively. The standard deviation is high (54465.39), thus there is high variability of this variable from the mean. The average value of the inflation variable (inf) is 14.20924 . The minimum and maximum values are 7.12635 and 26.67495 respectively. This variable has a low standard deviation (4.73252). This shows that there low variability from the mean. The mean of the real exchange rate (rer) is 91.1858 . The minimum and maximum values are 68.3678 and 107.5895 respectively. The variability of this variable from its mean is low as show by its standard deviation of 12.16606. GDP per capita (gdppc) has an average value 1288.467. The minimum and maximum values are 309.4845 and 2401.754 respectively. It has a low standard deviation value of 661.8778. This shows that there is low variability of this variable from the mean. Domestic credit to private sector (dcp) has a mean value of $4.80 \mathrm{E}+09$. The minimum and maximum values are $7.49 \mathrm{E}+08$ and $8.45 \mathrm{E}+09$ respectively. It has a low standard deviation value of $2.84 \mathrm{E}+09$. This is low, meaning low variability in the distribution of this variable from its mean. Private investment (pi) has a mean value of 7.36E+09. The minimum and maximum values are $1.21 \mathrm{E}+09$ and $1.67 \mathrm{E}+10$ respectively. It has a low standard deviation of $5.58 \mathrm{E}+09$. The average of market capitalisation (mcap) is $2.74 \mathrm{E}+09$. The minimum and maximum values are $3.50 \mathrm{E}+08$ and $5.71 \mathrm{E}+09$ respectively. Its variability from its mean is high as shown by its standard deviation of $1.75 \mathrm{E}+09$. 
Table 4. Kenya

\begin{tabular}{llcccc}
\hline & N & Mean & Std. Dev. & Min & Max \\
\hline pep & 16 & 424937.5 & 365003.7 & 185317.5 & 157289 \\
Inf & 16 & 9.64017 & 5.537859 & 1.961308 & 26.23982 \\
Rer & 16 & 80.14293 & 6.967529 & 67.31763 & 88.87352 \\
gdppc & 16 & 954.422 & 381.8652 & 395.8494 & 1594.835 \\
bcp & 16 & $1.21 \mathrm{E}+10$ & $7.27 \mathrm{E}+09$ & $3.40 \mathrm{E}+09$ & $2.32 \mathrm{E}+10$ \\
Pi & 16 & $8.10 \mathrm{E}+09$ & $4.28 \mathrm{E}+09$ & $1.99 \mathrm{E}+09$ & $1.44 \mathrm{E}+10$ \\
mcap & 16 & $1.36 \mathrm{E}+10$ & $8.22 \mathrm{E}+09$ & $1.43 \mathrm{E}+09$ & $3.20 \mathrm{E}+10$ \\
\hline
\end{tabular}

From table 4, the average of the private equity penetration (pep) variable for Kenya is 424937.5. The minimum and maximum values are 185317.5 and 157289 respectively. It has a high standard deviation value of 365003.7, thus high variability from the mean. Inflation (inf) has a mean of 9.64017. The minimum and maximum values are 1.961308 and 26.23982 respectively. It has a low standard deviation value of 5.537859; thus low variability from the mean. The mean value of real exchange rate (rer) is 80.14293 . The minimum and maximum values are 67.31763 and 88.87352 respectively. The variability of this variable from its mean is low as shown by the standard deviation of 6.967529. The average of the GDP per capita (gdppc) variable is 954.422 . The minimum and maximum values are 395.8494 and 1594.835 respectively. The variability of this variable from its mean is low as shown by its standard deviation of 381.8652. Domestic credit to private sector (dcp) has a mean of $1.21 \mathrm{E}+10$. The minimum and maximum values are $73.40 \mathrm{E}+09$ and $2.32 \mathrm{E}+10$ respectively. It has a low standard deviation of 7.27E+09. The mean of private investments (pi) is $8.10 \mathrm{E}+09$. The minimum and maximum values are $11.99 \mathrm{E}+09$ and $1.44 \mathrm{E}+10$ respectively. The variability from its mean is low as portrayed by its standard deviation of $4.28 \mathrm{E}+09$. The average of market capitalisation (mcap) is $1.36 \mathrm{E}+10$. The minimum and maximum values are $1.43 \mathrm{E}+09$ and $3.20 \mathrm{E}+10$ respectively. It has a high standard deviation value of $8.22 \mathrm{E}+09$. There is high variability in the distribution of this variable from the mean.

Table 5. Nigeria

\begin{tabular}{llcccc}
\hline & $\mathbf{N}$ & Mean & Std. Dev. & Min & Max \\
\hline pep & 16 & 232869.3 & 124042 & 111355.1 & 461293.3 \\
inf & 16 & 11.93949 & 3.48066 & 5.382224 & 17.86349 \\
rer & 16 & 99.27788 & 17.59897 & 72.70943 & 127.5896 \\
gdppc & 16 & 2008.153 & 762.5206 & 741.3403 & 3221.678 \\
bcp & 16 & $4.61 \mathrm{E}+10$ & $2.52 \mathrm{E}+10$ & $7.71 \mathrm{E}+09$ & $8.25 \mathrm{E}+10$ \\
pi & 16 & $6.00 \mathrm{E}+10$ & $1.71 \mathrm{E}+10$ & $2.63 \mathrm{E}+10$ & $8.98 \mathrm{E}+10$ \\
mcap & 16 & $4.58 \mathrm{E}+10$ & $2.46 \mathrm{E}+10$ & $2.37 \mathrm{E}+09$ & $8.85 \mathrm{E}+10$ \\
\hline
\end{tabular}

From table 5 above, the average of the private equity penetration (pep) in Nigeria variable is 232869.3. The minimum and maximum values are 111355.1 and 461293.3 respectively. The variability from its mean is low as shown by its standard deviation of 124042. The inflation variable (inf) has a mean of 11.93949. The minimum and maximum values are 5.382224 and 17.86349 respectively. It has a low standard deviation of 3.48066. The mean of the real exchange rate (rer) is 99.27788. The minimum and maximum values are 72.70943 and 127.5896 respectively. It has a low standard deviation of 17.59897. The average of the GDP per capita (gdppc) is 2008.153. The minimum and maximum values are 741.3403 and 3221.678 respectively. It has a low standard deviation of 762.5206. Domestic credit to private sector (dcp) has a mean value of $4.61 \mathrm{E}+10$. The minimum and maximum values are $7.71 \mathrm{E}+09$ and $8.25 \mathrm{E}+10$ respectively. It has a high standard deviation value of $72.52 \mathrm{E}+10$. Private investment (pi) has a mean of $6.00 \mathrm{E}+10$. The minimum and maximum values are $2.63 \mathrm{E}+10$ and $18.98 \mathrm{E}+10$ respectively. It has a low standard deviation value of $1.71 \mathrm{E}+10$. The average of market capitalisation (mcap) is $4.58 \mathrm{E}+10$. The minimum and maximum values are $2.37 \mathrm{E}+09$ and $8.85 \mathrm{E}+10$ respectively. It has a low standard deviation value of $2.46 \mathrm{E}+10$. 
Table 6. South Africa tatistics thus id South Africa

\begin{tabular}{lccccc}
\hline & Obs & Mean & Std. Dev. & Min & Max \\
\hline pep & 16 & 880561.2 & 328073.6 & 387509.3 & 1573199 \\
Inf & 16 & 5.393029 & 2.588241 & -0.69203 & 10.05528 \\
Rer & 16 & 88.1537 & 10.41198 & 72.01444 & 102.2357 \\
gdppc & 16 & 5769.099 & 1382.914 & 2461.355 & 7967.678 \\
bcp & 16 & $4.33 \mathrm{E}+11$ & $1.33 \mathrm{E}+11$ & $1.28 \mathrm{E}+11$ & $5.81 \mathrm{E}+11$ \\
Pi & 16 & $5.98 \mathrm{E}+10$ & $1.77 \mathrm{E}+10$ & $1.88 \mathrm{E}+10$ & $8.21 \mathrm{E}+10$ \\
mcap & 16 & $7.30 \mathrm{E}+11$ & $2.79 \mathrm{E}+11$ & $1.82 \mathrm{E}+11$ & $1.23 \mathrm{E}+12$ \\
\hline
\end{tabular}

From table 6 above, Private equity penetration (pep) in South Africa has a mean of 880561.2. The minimum and maximum values are 387509.3 and 1573199 respectively. It has a low standard deviation value of 328073.6. The average of the inflation variable (inf) is 5.393029. The minimum and maximum values are -0.69203 and 10.05528 respectively. It has a low standard deviation value of 2.588241 . The mean of the real exchange rate (rer) is 88.1537 . The minimum and maximum values are 72.01444 and 102.2357 respectively. It has a low standard deviation value of 10.41198. GDP per capita (gdppc) has a mean of 5769.099. The minimum and maximum values are 2461.355 and 7967.678 respectively. It has a low standard deviation value of 1382.914. Domestic credit to private sector (dcp) has a mean of $4.33 \mathrm{E}+11$. The minimum and maximum values are $1.28 \mathrm{E}+11$ and $5.81 \mathrm{E}+11$ respectively. It has a low deviation value of $1.33 \mathrm{E}+11$. The mean of the private investments (pi) variable is $5.98 \mathrm{E}+10$. The minimum and maximum values are $1.88 \mathrm{E}+10$ and $8.21 \mathrm{E}+10$ respectively. It has a low standard deviation value of $1.77 \mathrm{E}+10$. Market capitalisation (mcap) has a mean of $7.30 \mathrm{E}+11$. The minimum and maximum values are $1.82 \mathrm{E}+11$ and $1.23 \mathrm{E}+12$ respectively. It has a low standard deviation value of $2.79 \mathrm{E}+11$.

\section{Presentation and Discussion of Results}

\subsection{Pre- Estimation Test Results}

In order to ensure that there is no violation of panel data study that could produce unbiased coefficient estimates, the following pre-diagnostic tests were conducted prior to our regression results.

\subsubsection{Stationarity Results of Panels}

Table 7. Levin, Lin, and Chu Panel Unit Root Test Results

\begin{tabular}{lccc}
\hline \multicolumn{1}{c}{ Variables } & Levin, Lin and Chu Test Statistic & P-Value & Remark \\
\hline Lpep & -3.8833 & $0.0249^{* *}$ & $\mathrm{I}(0)$ \\
Lgdppc & -4.6420 & $0.0017^{*}$ & $\mathrm{I}(0)$ \\
Lmcap & -4.0329 & $0.0546^{* * *}$ & $\mathrm{I}(0)$ \\
LBCP & -4.5740 & $0.0001^{*}$ & $\mathrm{I}(0)$ \\
Lpi & -4.8305 & $0.0016^{*}$ & $\mathrm{I}(0)$ \\
LRer & -3.8218 & $0.0497^{* *}$ & $\mathrm{I}(0)$ \\
LInf & -7.4833 & $0.0000^{*}$ & $\mathrm{I}(0)$ \\
\hline
\end{tabular}

Note: $*$ significant at $1 \%, * *$ significant at $5 \%, * * *$ significant at $10 \%$

From the results in table 1 above, the null hypothesis of the test is that all panels contain unit root while the alternative hypothesis is that panels do not contain unit root. From the P-values it is evident that all the panels are stationary though at different levels of significance. Except for market capitalisation that is significant at 10 percent level of significance all the other variables are significant at 1 percent and 5 percent significance level.

5.1.2 Correlation and Multicollinearity Results

Table 8. Correlation Matrix

\begin{tabular}{|c|c|c|c|c|c|c|c|}
\hline & LPEP & LGDPPC & LBCP & LPI & INF & RER & LMCAP \\
\hline LPEP & 1 & & & & & & \\
\hline LGDPPC & 0.1358 & 1 & & & & & \\
\hline LBCP & 0.7121 & -0.2661 & 1 & & & & \\
\hline LPI & 0.5017 & -0.0957 & 0.886 & 1 & & & \\
\hline INF & -0.0628 & 0.1394 & -0.1407 & -0.0389 & 1 & & \\
\hline RER & -0.4233 & -0.0482 & -0.0392 & 0.0916 & -0.2556 & 1 & \\
\hline LMCAP & 0.5468 & 0.3108 & 0.8421 & 0.7506 & -0.3804 & 0.0104 & 1 \\
\hline
\end{tabular}

Table 8 above shows that a negative relationship exists between private equity penetration and inflation and also between private equity penetration and real exchange rate. This indicates that an increase in private equity 
penetration is associated with a decrease in these variables. It is also observed that a negative correlation exists between GDP per capita and bank credit to private sector; private investments and GDP per capita while a positive relationship exists between GDP per capita, inflation and market capitalisation. The relation between banking credit to private sector and other independent variables show that there is a positive relationship existing between banking credit to private sector and private investment and market capitalisation while the relationship between banking credit to private sector, inflation and real exchange rate is negative.

The magnitude of the correlation between the independent variables can also act as a prelude to detect the presence of multicollinearity. It is observed from the table that highest correlation coefficient $(0.8)$ exist between banking credit to private sector and private investments and between banking credit to private sector and market capitalisation. This may mean the existence of multicollinearity between banking credit to private sector and these variables. To support this, the VIF results are presented in Table 9 below.

Table 9. Multicollinearity Results

\begin{tabular}{lcc}
\hline Variable & VIF & 1/VIF \\
\hline LBCP & 8.07 & 0.123912 \\
LPI & 6.43 & 0.155642 \\
LMCAP & 4.85 & 0.206134 \\
INF & 1.62 & 0.617954 \\
LGDPG & 1.28 & 0.783656 \\
RER & 1.27 & 0.786867 \\
\hline Mean VIF & & 3.92 \\
\hline
\end{tabular}

The results show that the highest VIF occurs for banking credit to private sector with a value of 8.07 followed by private investments. The average VIF is 3.92. This is less than the maximum recommended VIF value of 10 and 5 by Hair (1995) and Ringle (2015) respectively. Therefore, our VIF shows that multicollinearity is not a major issue in our models.

\subsubsection{Results for Autocorrelation}

Table 10. Wooldridge and Wald Autocorrelation Test Results

\begin{tabular}{lllll}
\hline & Wooldridge & & Wald & \\
\hline Dependent Variable & F-Statistics & P-Value & F-Statistics & P-Value \\
\hline PEP model (4.8) & 229.662 & 0.0001 & 133.82 & $0.000^{*}$ \\
\hline
\end{tabular}

* Significant at 1 percent

The P-values of the Wooldridge and Wald tests for the private equity model is significant at 1 percent significant level indicating the presence of AR (1). Thus in the Panel Corrected Standard Errors and Feasible Generalised Least Squares analyses this is taken in to consideration.

\subsubsection{Results of Cross Sectional Independent}

The test results using the fixed effect and random effect analyses is presented table 11 below.

Table 11. Pesaran and Friedman cross sectional independence Test Results

\begin{tabular}{llllc}
\hline & RE & & FE & \\
\hline & Test statistics & P-Value & Test statistics & P-Value \\
\hline Pesaran & 9.181 & 0.0000 & 9.729 & $0.0000^{*}$ \\
Friedman & 57.918 & 0.0000 & 57.459 & $0.0000^{*}$ \\
Average absolute value of the off-diagonal elements & 0.726 & & 0.769 & \\
\hline
\end{tabular}

* Significant at 1 percent

The Pesaran and Friedman tests strongly reject the null hypothesis of no cross-sectional dependence. The average absolute correlation of the residuals is 0.726 and 0.769 for the RE and FE respectively. These values are very high thus suggesting the presence of cross-sectional dependence under both the FE and RE specifications. 


\subsubsection{Heteroskedasticity Test}

Table 12. Breusch-Pagan Heteroskedasticity Test Results

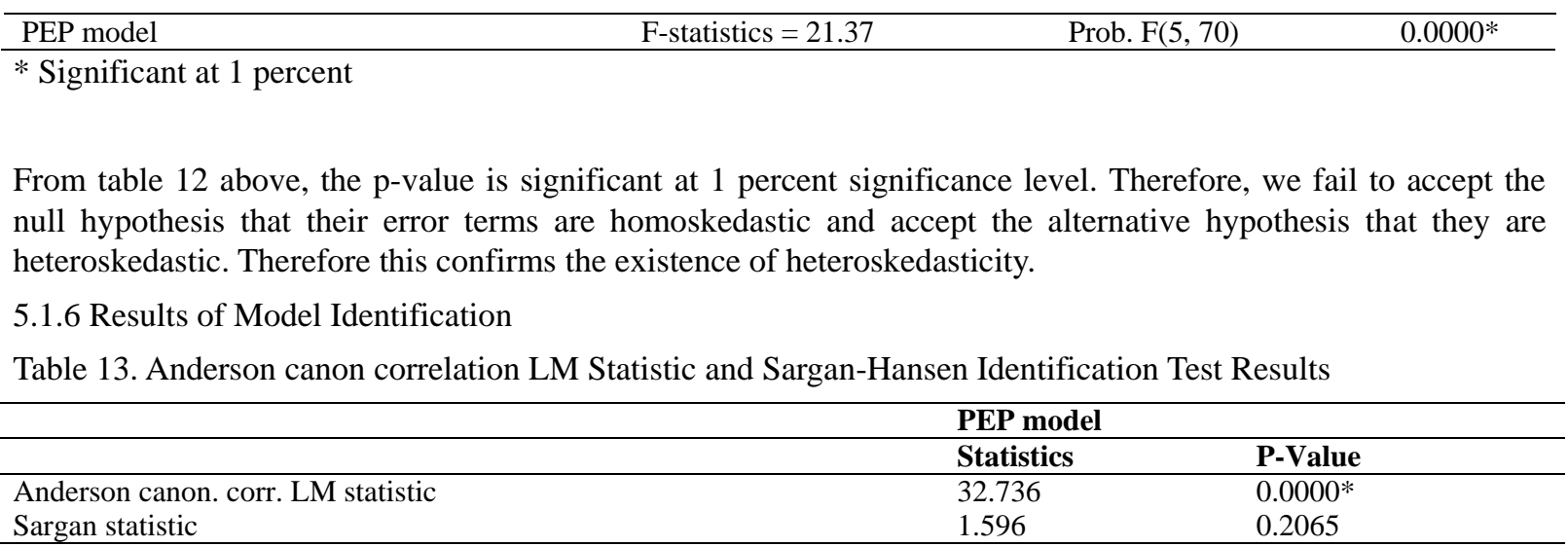

* Significant at 1 percent

The p-value of the Anderson canon correlation LM statistic is significant at 1 percent significance level. Therefore the null hypothesis that the model is underidentified is rejected. . Similarly, the P-value of the Sargan Statistic is insignificant at 5 percent significance level. Therefore we fail to reject the null hypothesis that the over-identifying restrictions are not valid. Therefore, there is no model under-identification problem. This means that the instruments used in the estimation are valid.

\subsubsection{Endogeneity Test Results}

Table 14. Sargan-Hansen Endogeneity Test Results

PEP model (Equation 4.8) $\quad$ Sargan statistic $=0.950 \quad$ Chi-sq(2) P-val $=0.3297$

The null hypothesis is that the independent variables are exogenous and the alternative is that private equity penetration is endogenous. Since the P-value is insignificant, we accept the null hypothesis that the independent variables in the model are exogenous and conclude that there is no endogeneity issue in this study.

\subsection{Regression Results}

Columns 1, 2, 3 below show the regression results using the panel Two Stage Least Squares Instrumental Variable (2SLS IV), Panel Corrected Standard Errors (PCSE) and Feasible Generalised Least Squares (FGLS) estimation techniques respectively. The results taking in to consideration the presence of autocorrelation of order one $(\mathrm{AR}(1))$ are estimated using both the PCSE and the FGLS estimation techniques.

Table 15. Panel 2SLS IV, PCSE and FGLS Estimation Results

\begin{tabular}{|c|c|c|c|c|}
\hline & & Panel 2SLS IV & PCSE & FGLS \\
\hline & & $\begin{array}{l}\text { Coefficient } \\
\text { (standard error) }\end{array}$ & $\begin{array}{c}\text { Coefficient } \\
\text { (standard error) }\end{array}$ & $\begin{array}{c}\text { Coefficient } \\
\text { (standard error) }\end{array}$ \\
\hline \multirow{2}{*}{\multicolumn{2}{|c|}{ LMCAP }} & $0.30863^{*}$ & $0.282218^{* *}$ & $0.2612078 * *$ \\
\hline & & $(0.158538)$ & $(0.0362206)$ & $(0.0379066)$ \\
\hline \multirow{2}{*}{\multicolumn{2}{|c|}{ LGDPPC }} & $0.635354 *$ & $0.804604 *$ & $0.712851 *$ \\
\hline & & (0.393294) & $(0.0935532)$ & $(0.0965029)$ \\
\hline \multirow{2}{*}{\multicolumn{2}{|c|}{ LBCP }} & $0.828666^{*}$ & 0.905849 & $0.958079 *$ \\
\hline & & $(0.453078$ & $(0.1568122)$ & $(0.06806822)$ \\
\hline \multirow{2}{*}{\multicolumn{2}{|c|}{ LPI }} & $1.181726 * * *$ & $0.258972 * * *$ & 0.428734 \\
\hline & & $(0.258733)$ & $(0.0 .004679)$ & $(0.3349939)$ \\
\hline \multirow{2}{*}{\multicolumn{2}{|c|}{ LNF }} & -0.00772 & $-0.00347 * *$ & $-0.02589 * *$ \\
\hline & & $(0.01182)$ & $(0.012356)$ & $(0.0125753)$ \\
\hline \multirow{2}{*}{\multicolumn{2}{|c|}{ LRER }} & $-0.01893^{*}$ & $-0.01667 * * *$ & $-0.01515 * * *$ \\
\hline & & (0.010134) & $(0.0035529)$ & $(0.0055495)$ \\
\hline \multicolumn{2}{|l|}{ Constant } & & $\begin{array}{c}0.282218 \\
(0.8440299)\end{array}$ & $\begin{array}{l}11.29616 \\
(1.420091)\end{array}$ \\
\hline $\begin{array}{l}\mathbf{R}-\text { Square } \\
\mathrm{F}(6,69)=\end{array}$ & 5.44 & Centered $=0.3170$ & 0.7867 & \\
\hline
\end{tabular}


$* * * 1 \%$ level of significance, $* 10 \%$ level of significance, $* * 5 \%$ level of significance

\section{Discussion of Regression Results}

From Table 15 above, our PEP model is well fitted as shown by F-test. The coefficient of determination R-square of the PCSE and FGLS model shows that about 78 percent of variations in private equity penetration is explained by the joint effect of all the variables in the model. This is an indication that the PEP model has a good fit.

The results using the three estimators (2SLS IV, Panel Corrected Standard error [PCSE] and Feasible Generalised Least Squares [FGLS]) show that the coefficient of stock market capitalisation is positive. This means that an increase in stock market capitalisation will lead to an increase in private equity penetration. In quantitative terms, the results of the 2SLS, IV estimator show that a 1 percent increase in stock market capitalisation will lead to a 0.30863 percent increase in private equity penetration. This positive effect is statistically significant at 10 percent level of significance. In quantitative terms, the results of the Panel Corrected Standard error and Feasible Generalised Least Squares estimation techniques show that 1 percent increase stock market capitalisation will lead to a 0.2822 percent increase in private equity penetration in the PCSE model and 0.26121 percent in FGLS model. This positive effect is statistically significant at 5 percent level of significance. These findings are supported by a priori expectation, modern portfolio theory, Neo-classical of investment behaviour and the findings of Groh and Liechtenstein (2010), Clarysse et al. (2009), Aizenman and Kendall (2008), Kelly (2012), Cherif and Gazdar (2011), Félix et al. (2013), Oino (2014), Bernoth and Colavecchio (2014) and Oni (2017. This result is inconsistent with the finding of Oino (2014). From our findings, a strong capital market creates a favourable environment for PE exits through initial public offerings and the provision of valuation data for Merger and Acquisition deals.

The coefficient of GDP per capita is positive for the three specifications. This means that an increase in GDP per capita will lead to an increase in private equity penetration. Specifically, the result of the 2SLS, IV shows that a $1 \%$ increase in GDP per capital will lead to a 0.635354 percent increase in private equity penetration. This effect is statistically significant at 10 percent level of significance. Using the PCSE and FGLS specifications, a 1 percent increase in GDP per capita will lead to a 0.804604 percent increase in private equity penetration for the PCSE model and 0.712851 percent for the FGLS model. This effect is statistically significant at 10 percent level of significance. The findings of the three techniques are consistent with the theoretical expectation, supported by the demand side of the Neo-Classical investment behaviour theory and consistent with the finding of Bernoth and Colavecchio (2014). From the findings, we can argue that when an individual's real national income increases his purchasing power and demand for goods and services also increase.

The coefficient of banking credit to private sector is also positive for the three specifications. This means that an improvement in banking credit to private sector will lead to an increase in private equity penetration. However, the results using the 2SLS IV estimation technique show that a 1 percent increase in banking credit to private sector will lead to a 0.828666 percent increase in private equity penetration. This result is statistically significant at 10 percent level of significance. The results using the using the PCSE and FGLS estimation techniques show that, a 1 percent increase in banking credit to private sector will lead to a 0.905849 percent increase in private equity penetration for the PCSE model and 0.958079 percent for the FGLS model. This result is statistically significant at 10 percent level of significance for the FGLS model and insignificant at the 10 percent level of significance for the PCSE Model. These three results are in accordance with theoretical expectations and the demand side of the neo-classical investment theory. The results using the 2SLS IV and FGSL are consistent with the findings of Guler and Guillén (2010). From our findings we posit that when productive credit is granted, it increases productivity and subsequently companies that will need to expand their productive capacities will demand more private equity funding.

Private Investment has a positive effect on private equity penetration for the three specifications. This means that an increase in private investments will lead to an increase in private equity penetration. In quantitative terms using the 2SLS IV estimator, a 1 percent increase in private investments will lead to a 1.18172 percent increase in private equity penetration. This result is statistically significant at 1 percent level of significance indicating that private investment is an important variable that determines private equity penetration in the selected countries. In quantitative terms using the PCSE and FGLS estimators, a 1 percent increase in private investments will lead to a 0.258972 percent increase in private equity penetration for the PCSE model and 0.428734 percent in the FGLS model. This result is statistically significant at 1 percent level of significance for the PCSE model and statistically insignificant at all levels of significance according to the FGLS model. The findings of all the 
three models are consistent with economic a priori expectation and the theory of neo-classical investment behaviour. From our results, we can posit that these countries use private equity funding to finance private investments in the form of gross domestic fixed capital formation.

The coefficient of inflation is negative for all the three estimation techniques. This means that an increase in the inflation will lead to a decrease in private equity penetration. Specific to the 2SLS IV estimator, an increase in inflation by 1 percent will lead to a 0.00772 percent decrease in private equity penetration. However, this result is statistically insignificant at 10 percent level of significance. Specific to the PCSE and FGLS estimators, an increase in inflation by 1 percent will lead to a -0.00347 percent decrease in private equity penetration for the PCSE model and -0.0258 percent for the FGLS model. However, this result is statistically significant at 5 percent level of significance for PCSE and FGLS models. These findings are consistent with a priori expectations, the supply side of the theory of investment behaviour and the modern portfolio theory. The finding using the 2SLS IV estimator is consistent with the findings with the findings of Bernoth and Colavecchio (2014) who found inflation to have a significant effect on private equity activity. The findings using the PCSE and FGLS are also inconsistent to that of Bernoth and Colavecchio (2014). From the results, we can posit that high inflation rates adversely affect private equity penetration in these countries as it increases investment risks and reduces investment returns due to difficulties to make projections.

The coefficient of real exchange rate is also negative for the three specifications. This means that an increase in exchange rate uncertainty will lead to a decrease in private equity penetration. Specific to the 2SLS IV estimator, an increase in exchange rate uncertainty by 1 percent will lead to a 1.893 percent decrease in private equity penetration. This result is statistically significant at 10 percent level of significance. Specific to the PCSE and FGLS specifications, an increase in exchange rate by 1 percent will lead to a -0.01667 percent decrease in private equity penetration for the PCSE model and -0.0151 percent for the FGLS model. This result is statistically significant at 1 percent level of significance for both PCSE and FGLS models. These finding are in accordance with a priori expectation, neo-classical investment behaviour and modern portfolio theories. From our findings, we can argue that real exchange rate uncertainty is a common characteristic of the selected countries because of their underdeveloped financial systems. Private equity investors are known to react negatively to currency risks.

\section{Conclusions and Policy Recommendations}

From the findings, the signs of all the variables using the three specifications are the same though the magnitudes are different. However, inflation is insignificant using the 2SLS estimation technique and significant in the PCSE and FGLS models. It can also be observed that in terms of PCSE and FGLS estimation techniques used, banking credit to private sector is insignificant in the PCSE model while private investments is insignificant in the FGLS model. GDP per capita, real exchange rate, stock market capitalisation are significant using the three estimation techniques. The findings showed that stock market capitalisation, GDP per capita, banking credit to private sector and private investments had significant and positive effects on private equity penetration and should be considered as important drivers of private equity penetration in the selected African countries. On the other hand, real exchange rates and inflation had significant and negative effects on private equity penetration and should equally be considered as important drivers of private equity penetration in the selected Sub-Sahara Countries. This means that these variables should be considered by policy makers when discussing and implementing policies that will increase and promote private equity penetration/activity in these countries.

On stock market capitalisation, policy makers should formulate and implement policies that will increase the number of listed companies by setting listing requirements based on businesses sizes. This is in order to give every business the opportunity to participate in stock market activities. A rigorous education and marketing campaign on the advantages of listing should follow including the Diaspora. On the improvement of GDP per capital, we recommend these governments to have favourable macroeconomic environments that will increase productivity. On banking credit to the private sector, we suggest that these governments should formulate policies that will increase the development of micro-credit institutions as they are known to grand micro-credits of a majority of their populations than commercial banks. In terms of inflation, we recommend that policy makers in these countries should maintain inflation at threshold levels by urging their central banks to pursue inflation targeting. The outcome of this targeting should be to keep inflation at a lower rate in order to ensure macroeconomic and financial stability. On real rate of exchange, we recommend that the central banks of these countries should take measures to stabile the exchange rate of their currencies in order to ensure exchange rate certainty. To promote private investments in these countries, we recommend that these countries should ensure friendly business environments. This could be done by taking and implementing measures that will eliminate corruption and political patronage in government decision making. They should also Fast-track the 
computerisation of government processes.

\section{Acknowledgements}

We are grateful to the secretary general of the Douala Stock Exchange for his enormous contribution during the process of data collection.

\section{References}

Africa Private Equity and Venture Capital Association. (March, 2019). Annual private equity data tracker. Retrieved from https://www.avca-africa.org/research-publications/data-reports/2018-annual-african-private-equity-data-trac ker

Aizenman, J., \& Kendall, J. (2012). The internationalization of venture capital. Journal of Economic Studies, 39(5), 488-511. https://doi.org/10.1108/01443581211259446

Beck, N., \& Katz, J. N. (1995). What to do (and not to do) with time-series cross-section data. American Political Science Review, 89(3), 634-647. https://doi.org/10.2307/2082979

Belke, A. H., Fehn, R., \& Foster-McGregor, N. (2003). Does venture capital investment spur employment growth? Journal of Venturing, 56(3), 232-248. Retrieved from https://EconPapers.repec.org/RePEc:vie:viennp:0303

Bernoth, K., \& Colavecchio, R. (2014). The macroeconomic determinants of private equity investment: a European comparison. Applied Economics, 46(11), 1170-1183. https://doi.org/10.1080/00036846.2013.866306

Cherif, M., \& Gazdar, K. (2011). What drives venture capital investments in Europe? New results from a panel data analysis. Journal of Applied Business and Economics, 12(3), 122-139.

Clarysse, B., Knockaert, M., \& Wright, M. (2009). Benchmarking UK venture capital to the US and Israel: what lessons can be learned. Report for British private equity and venture capital association.

Cressy, R., Munari, F., \& Malipiero, A. (2007). Playing to their strengths? Evidence that specialization in the private equity industry confers competitive advantage. Journal of Corporate Finance, 13(4), 647-669.

Ernst \& Young. (2018). How to make Sense today of private equity. Retrieved from www.ey.com/en_gl/private-equity/how-to-make-sense-of-today-s-private-equity-market

European Venture Capital Association. (2013). Exploring the Impact of Private Equity on Economic Growth in Europe. Frontier Economics Ltd, London.

Félix, E. G. S., Pires, C. P., \& Gulamhussen, M. A. (2013). The determinants of venture capital in Europe. Evidence across countries. Journal of Financial Services Research, 44(3), 259-279. https://doi.org/10.1007/s10693-012-0146-y

Groh, A. P., von Liechtenstein, H., \& Lieser, K. (2010). The European venture capital and private equity country attractiveness indices. Journal of Corporate Finance, 16(2), 205-224. https://doi.org/10.1016/j.jcorpfin.2009.09.003

Guler, I., \& Guillén, M. F. (2010). Institutions and the internationalization of US venture capital firms. Journal of International Business Studies, 41(2), 185-205. https://doi.org/10.1057/jibs.2009.35

Hair, J. F., Anderson, R. E., Tatham, R. L., \& Black, W. C. (1995). Multivariate dataanalysis with readings. Englewood Cliff, NJ: Prentice.

International Monetary Fund. (2015). Making Public Investment More Efficient. Policy paper. https://doi.org/10.5089/9781498344630.007

Jorgenson, D. W. (1971). Econometric studies of investment behavior: A survey. Journal of Economic Literature, 9(4), 1111-1147.

Kelly, R. (2012). Drivers of private equity investment activity: are buyout and venture investors really so different? Venture Capital, 14(4), 309-330. https://doi.org/10.1080/13691066.2012.688494

Leamon, A., \& Lerner, J. (2011). Creating a venture ecosystem in Brazil: FINEP's INOVAR Project. Harvard business school.

Markowitz, H. (1952). Portfolio selection. The Journal of Finance, 7(1), 77-91. https://doi.org/10.1111/j.1540-6261.1952.tb01525.x 
Ministry of the Economy, Planning and Regional Development. (2013). Investing in Cameroon

Modigliani, F., \& Miller, M. H. (1958). The cost of capital, corporation finance and the theory of investment. The American, 1, 3 .

Molatlhwe, L. (2015). Private equity growth in emerging markets: a South African case study (Master's thesis, University of Pretoria, South Africa). Retrieved from https://repository.up.ac.za/bitstream/handle/2263/52261/Molatlhwe_Private_2016.pdf?sequence=1

Myers, S. C. (1984). The capital structure puzzle. The Journal of Finance, 39(3), 574-592. https://doi.org/10.1111/j.1540-6261.1984.tb03646.x

Njubi, T. W. (2018). Factors that influence venture capitalist's decision in funding Small Medium Enterprises in Kenya (Masters thesis, Strathmore University, Nairobi, Kenya). Retrieved from https://pdfs.semanticscholar.org/2030/ab5ddd91561a7223171ba91ca18eb4ae73c1.pdf

Oino, I. (2014). The macroeconomic and environmental determinants of private equity in emerging Asia market: The application of extreme bounds analysis. Journal of Investment and Management, 3(3), 51-60. https://doi.org/10.11648/j.jim.20140303.12

Oni, O. (2017). Determinants of Venture Capital Supply in Sub-Saharan Africa. Journal of Economics and Behavioral Studies, 9(4), 87-97. https://doi.org/10.22610/jebs.v9i4.1824

Owusu-Adjei, K. (2010). A survey of the Ghanaian private equity industry and its contribution to private sector development (Bachelor's Thesis, University of Ghana). Retrieved from http://hdl.handle.net/20.500.11988/157

Parks, R. W. (1967). Efficient estimation of a system of regression equations when disturbances are both serially and contemporaneously correlated. Journal of the American Statistical Association, 62(318), 500-509. https://doi.org/10.1080/01621459.1967.10482923

Ringle, C., Da Silva, D., \& Bido, D. (2015). Structural equation modeling with the Smart PLS. Brazilian Journal Of Marketing, 13(2). https://doi.org/10.5585/remark.v13i2.2717

Securities and Exchange Commission. (2016). Trends in Private Equity Market. SEC Learning series.

Yan, J. (2011). Merger waves: Theory and evidence. The Quarterly Journal of Finance, 1(03), 551-606. https://doi.org/10.1142/S201013921100016X

\section{Copyrights}

Copyright for this article is retained by the author(s), with first publication rights granted to the journal.

This is an open-access article distributed under the terms and conditions of the Creative Commons Attribution license (http://creativecommons.org/licenses/by/4.0/). 